Our Nature (2009) 7:207-211

\title{
Checklist of Fish Species Richness of Jai Prakash Narayan Bird Sanctuary, Suraha Lake, Ballia, U.P., India
}

\author{
P.K. Srivastava* and S.J. Srivastava \\ Fish Biology Lab., Department of Zoology, S.M.M.T.D. College Ballia, U.P., India \\ *E-mail: pksrivastava17@yahoo.co.in
}

Received: 21.01.2009, Accepted: 09.04.2009

\begin{abstract}
Present paper deals with the fish species richness of the Suraha Lake. The study was made during August 2002-July 2004. In the course of investigation at three sampling spots Mairitar, Surajpura and Basantpur, 54 fish species were recorded under 7 orders and 20 families. Twentyone species of Cypriniformes, 12 species of Siluriformes, 3 species of Symbrachiformes, 13 species of Perciformes, 1 species of Tetradontiformes, 3 species of Clupeiformes and 1 species of Beloniformes have been recorded.
\end{abstract}

Key words: Jai Prakash Narayan Bird Sanctuary, Suraha lake, fish species richness

\section{Introduction}

Suraha Lake is an important natural resource for fisheries in the Ballia district in eastern Uttar Pradesh. It is a good resource for capture fisheries in this region; it forms the lifeline for rural economy and environment of this area. It has a great recreational value and it also supports local agriculture, irrigation and tourism. It is an open type oval ' $U$ ' shaped ox-bow natural (river meandering) lake in the flood plain of river Ganga, located $8 \mathrm{~km}$ north to the district head quarters of Ballia (Figure 1). It is a perennial meander of the river Ganga with an area of 2602.18 ha. During monsoon season it covers about 3642.25 ha. It is situated in between $25^{\circ} 48^{\prime}$ to $25^{\circ} 52^{\prime} \mathrm{N}$ and $84^{\circ} 8^{\prime}$ to $84^{\circ} 13^{\prime} \mathrm{E}$; altitude $166 \mathrm{msl}$. The lake circumference is about $25.6 \mathrm{~km}$. The lake has openly connected with river Ganga through Katehar nullaha, its length is about $32.6 \mathrm{~km}$ which is drained and filled according to the water level of the river. It also receives huge amount of runoff water from adjoining area through Madha and Garari nullahas. The lake water drains out by Nakta and Suraha tal canal system.

\section{Materials and methods}

During the period of study, intensive faunistic surveys of the lake were carried out by monthly sampling from August 2002 to September 2004. Fish collection was made from the catches of fishers from the three spots of the lake i.e., Mairitar, Surajpura and Basantpur. The fishing was done by gill net, trap and angling. After the collection of fish, the small specimens were immediately preserved in $10 \%$ formalin and brought to lab for identification. The identification was made with the help of taxonomic references from Jhingran (1975), Linderberg (1976), Day (1978), Srivastava (1986), Talwar and Jhingran (1992) and Jayaram (1999).

\section{Results and discussion}


P.K. Srivastava and S.J. Srivastava / Our Nature (2009) 7: 207-211

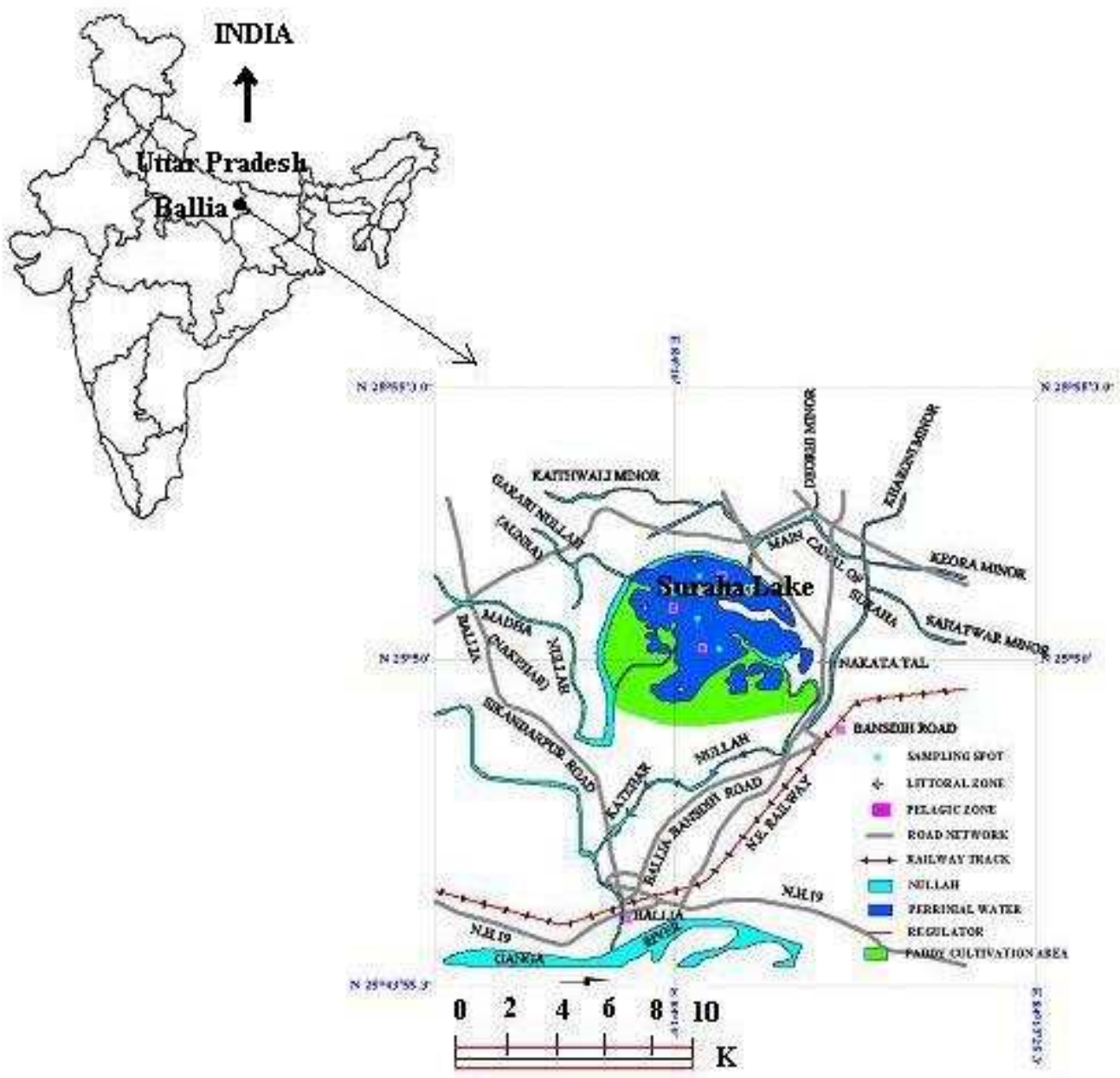

Figure 1. Schematic map of Jai Prakash Narayan Bird Sanctuary (Suraha Lake)

Table 1. Taxonomic list of fish species recorded from Suraha Lake.

\begin{tabular}{llllll}
\hline S.N. & Taxonomic position and scientific name & Vernacular name & Spot I & Spot II & Spot III \\
\hline & Order: Cypriniformes & & & & \\
& Family: Cyprinidae & Bhakur & $\sqrt{ }$ & - & $\sqrt{ }$ \\
1. & Catla catla (Hamilton) & Nain & - & $\sqrt{ }$ & - \\
2. & Cirhinus mrigala (Hamilton) & Raeya & $\sqrt{ }$ & - & $\sqrt{ }$ \\
3. & Cirrhinus reba (Hamilton) & Grass & - & $\sqrt{ }$ & - \\
4. & Ctenopharyngodon idella (Valenciennes) & Silvar & $\sqrt{ }$ & $\sqrt{ }$ & $\sqrt{ }$ \\
5. & Cyprinus carpio (Linn.) & Bata & $\sqrt{ }$ & - & - \\
6. & Labeo bata (Hamilton) & Karauchar & $\sqrt{ }$ & - & - \\
7. & Labeo calbasu (Hamilton) & Kursa & $\sqrt{ }$ & $\sqrt{ }$ & - \\
8. & Labeo gonius (Hamilton) & Rohu & $\sqrt{ }$ & $\sqrt{ }$ & - \\
9. & Labeo rohita (Hamilton) & Gurda & $\sqrt{ }$ & - & $\sqrt{ }$
\end{tabular}


P.K. Srivastava and S.J. Srivastava / Our Nature (2009) 7: 207-211

\begin{tabular}{|c|c|}
\hline 11. & Puntius chola (Hamilton) \\
\hline 12. & Puntius sarana (Hamilton) \\
\hline 13. & Puntius sophore (Hamilton) \\
\hline 14. & Puntius ticto (Hamilton) \\
\hline 15. & Rasbora daniconius (Hamilton) \\
\hline 16. & Salmostome bacaila (Hamilton) \\
\hline 17. & Securicula gora (Hamilton) \\
\hline 18. & Amblypharyngodon mola (Hamilton) \\
\hline \multirow[t]{2}{*}{19.} & Aspidoparia morar (Hamilton) \\
\hline & Family: Cobitidae \\
\hline 20. & Lepidocephalichthys guntea (Hamilton) \\
\hline \multirow[t]{3}{*}{21.} & Botia dario (Hamilton) \\
\hline & Order: Siluriformes \\
\hline & Family: Bagriidae \\
\hline 22. & Seperata aor (Hamilton) \\
\hline 23. & Mystus vittatus (Bloch) \\
\hline 24. & Mystus tengara (Hamilton- Buchanon) \\
\hline \multirow[t]{2}{*}{25.} & Mystus bleekeri (Day) \\
\hline & Family: Siluridae \\
\hline 26. & Ompok bimaculatus (Bloch) \\
\hline \multirow[t]{2}{*}{27.} & Wallago attu (Bloch \& Schneider) \\
\hline & Family: Schilbeidae \\
\hline 28. & Ailia coila (Hamilton) \\
\hline 29. & Clupisoma garua (Hamilton) \\
\hline 30. & Eutropiichthys vacha (Hamilton) \\
\hline \multirow[t]{2}{*}{31.} & Pseudeutropius buchanani (Valencienn \\
\hline & Family : Clariidae \\
\hline \multirow[t]{2}{*}{32.} & Clarias batracus (Linnaeus) \\
\hline & Family : Heteropneustidae \\
\hline \multirow[t]{3}{*}{33.} & Heteropneustes fossilis (Bloch) \\
\hline & Order : Synbranchiformes \\
\hline & Family : Mastacembelidae \\
\hline 34. & Mastacembelus armatus (Lacepede) \\
\hline \multirow[t]{2}{*}{35.} & Mastacembelus puncalus (Hamilton) \\
\hline & Family : Synbranchidae \\
\hline \multirow[t]{3}{*}{36.} & Monopterus cuchia (Hamilton) \\
\hline & Order : Perciformes \\
\hline & Family : Channidae \\
\hline 37. & Channa marulius (Hamilton) \\
\hline 38. & Channa punctatus (Bloch) \\
\hline 39. & Channa striatus (Bloch) \\
\hline 40. & Channa gachua (Hamilton) \\
\hline \multirow[t]{2}{*}{41.} & Channa orientalis (Bloch \& Schneider) \\
\hline & Family : Osphronemidae \\
\hline 42. & Colisa fasciata (Bloch \& Schneider) \\
\hline \multirow[t]{2}{*}{43.} & Colisa latius (Bloch) \\
\hline & Family : Chandidae \\
\hline 44. & Chanda nama (Hamilton) \\
\hline \multirow[t]{2}{*}{45.} & Parambassis ranga (Hamilton) \\
\hline & Family : Anabantidae \\
\hline \multirow[t]{2}{*}{46.} & Anabas testudineus (Bloch) \\
\hline & Family : Nandidae \\
\hline 47. & Nandus nandus (Hamilton) \\
\hline
\end{tabular}

Sidhari
Darhi
Sidhari
Sidhari
Dadula
Chalhawa
Dariyae chalhawa
Dhawaie
Kaywachi harda
Nakhi
Bghaua

Dariyae tengar

Tangara

Tangara

Baikhari

Jalkapur

Barari

Patasi

Baykari

Bhayghu

Barusa

Magur

Shinghi

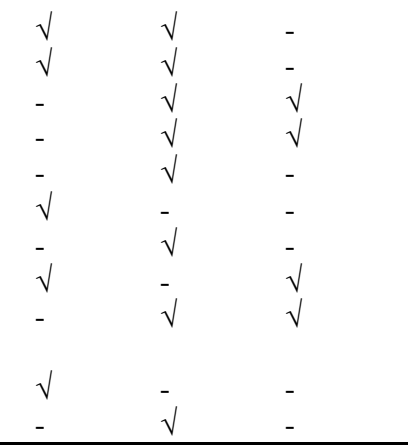

Bam

Patya

Anha bam

Saur

Girae

Saur

Chanaga

Chanaga

Khosti

Khosti

Chanari

Chanari

Sumha

Dhebari 
P.K. Srivastava and S.J. Srivastava / Our Nature (2009) 7: 207-211

\begin{tabular}{|c|c|c|c|c|c|}
\hline 48. & $\begin{array}{l}\text { Family : Gobiidae } \\
\text { Glossogobius giuris (Hamilton) } \\
\text { Family : Sciaenidae }\end{array}$ & Bulla & $\sqrt{ }$ & $\sqrt{ }$ & $\sqrt{ }$ \\
\hline 49. & Johnius coitor (Hamilton) & Bhola & $\sqrt{ }$ & - & $\sqrt{ }$ \\
\hline 50. & $\begin{array}{l}\text { Order : Tetrdontiformes } \\
\text { Family : Tetradontidae } \\
\text { Tetradon fluviatilis (Hamilton) }\end{array}$ & Beng macharia (Galari) & $\sqrt{ }$ & - & - \\
\hline & $\begin{array}{l}\text { Order: Clupeiformes } \\
\text { Family: Clupeidae }\end{array}$ & & & & \\
\hline 51. & Gudusia chapra (Hamilton) & Suhia & $\sqrt{ }$ & - & $\sqrt{ }$ \\
\hline 52. & $\begin{array}{l}\text { Gonialosa manmina (Hamilton) } \\
\text { Family: Engraulidae }\end{array}$ & Maghali suhia & $\sqrt{ }$ & - & - \\
\hline 53. & Setipinna phasa (Hamilton) & Phasi & $\sqrt{ }$ & - & $\sqrt{ }$ \\
\hline 54. & $\begin{array}{l}\text { Order: Beloniformes } \\
\text { Family: Belonidae } \\
\text { Xenentodon cancila (Hamilton) } \\
\text { Prawn }\end{array}$ & Kauwa & $\sqrt{ }$ & $\sqrt{ }$ & $\sqrt{ }$ \\
\hline 55. & Macrobrachium lamarrei (H.Milne-Edwards) & Jhinga & $\sqrt{ }$ & - & - \\
\hline
\end{tabular}

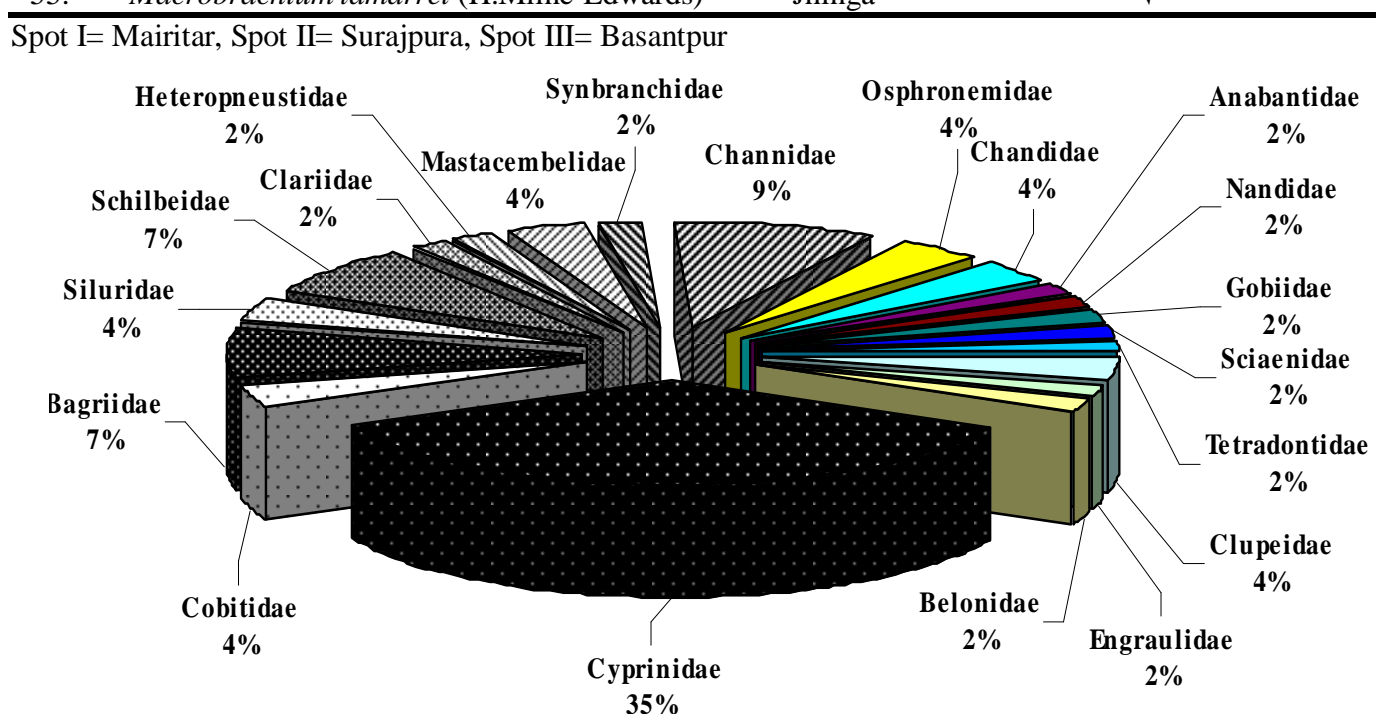

Figure 2. Percent contribution of families.

Total 53 fish species were recorded at three spots during the study, taxonomic position, local name and spot of collection of the individual fish species are listed in Table 1. The maximum number of 37 fish species were recorded from the Maritar and minimum number 28 fish species recorded from Basantpur. During the period of investigation 21 species of Cypriniformes (including 2 exotic species i.e. Cyprinus carpio and Ctenopharyngodon idella) from the lake, 12 species from Siluriformes, 3 species from Symbrachiformes, 13 species from Perciformes, 1 species from Tetradontiformes, 3 species from Clupeiformes and 1 species from Beloniformes (Figure 2). Cypriniformes contributed maximum of $36 \%$ fish species. The catch composition of lake was Indian major carps $15-20 \%$, minor carps $2-5 \%$, catfishes and fetherbacks 35- 
P.K. Srivastava and S.J. Srivastava / Our Nature (2009) 7: 207-211

$40 \%$, live fishes $5-10 \%$, forage fishes 15 20\%. Unfortunately, the Indian Major Carps have declined sharply in the last one decade with forage and catfishes increasing dramatically in the lake. The maximum fish species were collected during the summer season. The climatic factors may have directly affected the availability of fish species. Previously, Swarup and Singh (1975) listed 51 fish species in the same lake. The fish composition showed similarity with the species of the Ganga river system because it openly connected with river and provides good breeding and nursery ground for fishes and spawns. Indiscriminate fishing has been observed during the entire study period which might have resulted in tremendous decrease of major carps. Many workers worked on fish species richness of the different aquatic system in India. Menon (1974) has listed 141 species, belonging to 72 genera, 30 families and 11order from Ganga river system.

According to fishers assumption, the fish catch of the Suraha lake has been declined during the last two decades, may be due to climate change, indiscriminate fishing of brood stock in the spawning ground and use of smaller mesh size of fishing net.

\section{Suggestions}

Fish sanctuary should establish to preserve fish stock and indigenous brooder. Fishery regulation should strictly apply for protection of fish species and enhanced the fish production especially Indian major carps. Indian major carps are highly priced fishes, but their stocks are going to decline; to conserve the Indian major carp less than 2 $\mathrm{cm}$. mesh size nets should be strictly banned in this lake. Pen and cage culture should practiced for enhance the carp production.
Fishermen have reported that due to declination of fish catch many of them have forced to migrate and change their profession. During this study it has also been observed that water area has been heavily chocked with macrophyte vegetation and encroached by farmers for protection of this lake local govt. should take care and apply some rules because good habitat is an essential for fishery improvement.

\section{Acknowledgements}

The authors are highly grateful to Dr. M.K. Das, Principal Scientist and Head, Fish Health and Environment Division, Central Inland Fisheries Research Institute, Barrackpore, Kolkata for critically going through the manuscript and his valuable suggestions.

\section{References}

Day, F. 1978. The fishes of India being a natural history of the fishes known to inhabit the seas and freshwater of India, Burma and Ceylon, Vol. I \& II, William Dawson and Sons Ltd., London, pp. 20778 .

Jayaram, K.C. 1999. The freshwater fishes of the Indian region. Narendra Publishing House, Delhi. 571p.

Jhingran, V.G. 1975. Fish and fisheries of India. Hindustan Publishing Corporation (India). 954p.

Linderberg, G.V. 1976. Fishes of the world. A key to families and checklist. John Wiley and Sons, New York.545p.

Menon, A.G.K. 1974. A check list Fishes of Himalayan and the Indo-Gangetic plains. Special publication IFSI. 1: 1-136.

Srivastava, G.L. 1986. Fishes of Eastern Uttar Pradesh. Vishwavidyalaya Prakashan, Varanasi.163p.

Swarup, K. and S.R. Singh 1975. The fisheries of Suraha Tal, Ballia, Uttar Pradesh. J. Zoo. Soc. of India. pp. 180-184.

Talwar, P.K. and A.K. Jhingran 1992. Inland fishes of India and adjacent countries. Vol. 1. A.A. Balkema/Rotterdam. 1177p. 